\title{
Front Matter: Volume 9542
}

, "Front Matter: Volume 9542," Proc. SPIE 9542, Medical Laser Applications and Laser-Tissue Interactions VII, 954201 (22 July 2015); doi:

10.1117/12.2206215

SPIE. Event: European Conferences on Biomedical Optics, 2015, Munich, Germany 


\title{
Medical Laser Applications and Laser-Tissue Interactions VII
}

\author{
Lothar D. Lilge \\ Ronald Sroka \\ Editors
}

\section{1-23 June 2015}

Munich, Germany

Sponsored by

SPIE (United States)

The Optical Society of America (United States)

With Support From

ThorLabs (United Kingdom)

Topcon (Japan)

Toptica Photonics AG (Germany)

Zeiss (United States)

Published by

SPIE 
The papers included in this volume were part of the technical conference cited on the cover and title page. Papers were selected and subject to review by the editors and conference program committee. Some conference presentations may not be available for publication. The papers published in these proceedings reflect the work and thoughts of the authors and are published herein as submitted. The publisher is not responsible for the validity of the information or for any outcomes resulting from reliance thereon.

Please use the following format to cite material from this book:

Author(s), "Title of Paper," in Medical Laser Applications and Laser-Tissue Interactions VII, edited by Lothar D. Lilge, Ronald Sroka, Proceedings of SPIE-OSA Biomedical Optics Vol. 9542 (SPIE, Bellingham, WA, 2015) Article CID Number.

ISSN: 1605-7422

ISBN: 9781628417074

\section{Copublished by}

\section{SPIE}

P.O. Box 10, Bellingham, Washington 98227-0010 USA

Telephone +1 3606763290 (Pacific Time) · Fax +1 3606471445

SPIE.org

and

\section{The Optical Society}

2010 Massachusetts Ave., N.W., Washington, D.C., 20036 USA

Telephone 1 202/223-8130 (Eastern Time) · Fax 1 202/223-1096

http://www.osa.org

Copyright (c) 2015, Society of Photo-Optical Instrumentation Engineers and The Optical Society

Copying of material in this book for internal or personal use, or for the internal or personal use of specific clients, beyond the fair use provisions granted by the U.S. Copyright Law is authorized by SPIE subject to payment of copying fees. The Transactional Reporting Service base fee for this volume is $\$ 18.00$ per article (or portion thereof), which should be paid directly to the Copyright Clearance Center (CCC), 222 Rosewood Drive, Danvers, MA 01923. Payment may also be made electronically through CCC Online at copyright.com. Other copying for republication, resale, advertising or promotion, or any form of systematic or multiple reproduction of any material in this book is prohibited except with permission in writing from the publisher. The CCC fee code is $1605-7422 / 15 / \$ 18.00$.

Printed in the United States of America.

Publication of record for individual papers is online in the SPIE Digital Library.

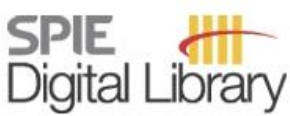

SPIEDigitalLibrary.org

Paper Numbering: Proceedings of SPIE follow an e-First publication model, with papers published first online and then in print. Papers are published as they are submitted and meet publication criteria. A unique citation identifier (CID) number is assigned to each article at the time of the first publication. Utilization of CIDs allows articles to be fully citable as soon as

they are published online, and connects the same identifier to all online, print, and electronic versions of the publication. SPIE uses a six-digit CID article numbering system in which:

- The first four digits correspond to the SPIE volume number.

- The last two digits indicate publication order within the volume using a Base 36 numbering

system employing both numerals and letters. These two-number sets start with 00, 01, 02, 03, 04, $05,06,07,08,09,0 A, 0 B \ldots$. 0Z, followed by 10-1Z, 20-2Z, etc.

The CID Number appears on each page of the manuscript. The complete citation is used on the first page, and an abbreviated version on subsequent pages. 


\title{
Contents
}

\author{
vii Authors \\ ix Conference Committee \\ xi Introduction
}

SESSION 1 PHOTOSENITIZER AND NANOPARTICLE MEDIATED PDT

954204 Photodynamic effects of gold nanoparticles in a breast cancer cell line (MCF-7) in vitro [9542-3]

954205 Metal nanoparticles of different shapes influence on optical properties of multilayered biological tissues [9542-4]

954206 Review of dermatology use of 5-aminolevulinic acid photodynamic therapy in China from 1997 to 2013 [9542-5]

\section{SESSION 2 LASERS AND LIGHT IN THE BRAIN}

954207 Optical properties of the deep brain in the red and NIR: changes observed under in-vivo, post-mortem, frozen, and formalin-fixated conditions (Invited Paper) [9542-6]

954208 Optical spectroscopy for stereotactic biopsy of brain tumors [9542-7]

$9542 \mathrm{OB}$ In vitro study for photodynamic therapy using Fotolon in glioma treatment [9542-10]

\section{SESSION $3 \quad$ APPLICATION OF LASER IN SOFT TISSUE}

9542 0C Thulium fiber laser damage to the ureter (Invited Paper) [9542-11]

9542 OD Endovenous laser therapy for occlusion of incompetent saphenous veins using 1940nm [9542-12]

9542 OE Impact of terahertz radiation on the epithelialization rate of scarified cornea [9542-13]

9542 OF Healing process study in murine skin superficial wounds treated with the blue LED photocoagulator EMOLED [9542-14]

$95420 \mathrm{G}$ Comparison of four lasers $(\lambda=650,808,980$, and $1075 \mathrm{~nm})$ for noninvasive creation of deep subsurface lesions in tissue [9542-15] 


\section{SESSION 4 LASER TREATMENT MONITORING AND FEEDBACK CONTROL}

9542 Ol Towards advanced OCT clinical applications (Invited Paper) [9542-17]

9542 0J $980 \mathrm{~nm}$ diode laser with automatic power control mode for dermatological applications [9542-18]

9542 OK Analysis of radiation parameters to control the effects of Nd:YAG laser surgery on gastric malignancies [9542-19]

$95420 \mathrm{M}$ Investigation of the optical properties of normal fibroblasts and fibroblasts cultured with cancer cells in terahertz frequency range [9542-21]

$95420 \mathrm{~N}$ Terahertz pulsed imaging study of dental caries [9542-22]

SESSION 5 APPLICATION OF LASERS IN HARD TISSUES

954200 Differentiation of tissue and kidney stones for laser lithotripsy using different spectroscopic approaches (Invited Paper) [9542-23]

9542 OP Fast and automatic depth control of iterative bone ablation based on optical coherence tomography data [9542-24]

$95420 Q \quad$ Investigations of the damage mechanisms during ultrashort pulse laser ablation of dental tissue [9542-25]

\section{SESSION 6 LASERS IN OPTHALMOLOGY}

9542 OT Ultrafast laser machining of porcine sclera [9542-28]

9542 OW Pore size assessment during corneal endothelial cells permeabilization by femtosecond laser activated carbon nanoparticles [9542-31]

POST-DEADLINE SESSION

$95420 Z \quad$ Ultrafast laser ablation for targeted atherosclerotic plaque removal [9542-44]

POSTER SESSION

954213 Assessment of the effective attenuation coefficient of scattering media illuminated by an LED array: effect of the beam size [9542-37]

954216 Histological study of subcutaneous fat at NIR laser treatment of the rat skin in vivo [9542-40] 
954217 Electrical stimulation vs. pulsed and continuous-wave optical stimulation of the rat prostate cavernous nerves, in vivo [9542-41]

954218 Experimental investigation on light propagation through apple tissue structures [9542-42]

95421 A Miniature LED endoilluminators for vitreoretinal surgery [9542-45]

9542 1B Precision machining of pig intestine using ultrafast laser pulses [9542-46]

9542 ID Pulse mode irradiation at Radachlorin PDT shifted cell death to apoptosis in vitro [9542-48] 
Proc. of SPIE-OSA Vol. 9542 954201-6 Downloaded From: https://www.spiedigitallibrary.org/conference-proceedings-of-spie on 25 Apr 2023
Terms of Use: https://www.spiedigitallibrary.org/terms-of-use 


\section{Authors}

Numbers in the index correspond to the last two digits of the six-digit citation identifier (CID) article numbering system used in Proceedings of SPIE. The first four digits reflect the volume number. Base 36 numbering is employed for the last two digits and indicates the order of articles within the volume. Numbers start with 00, 01, 02, 03, 04, 05, 06, 07, 08, 09, 0A, OB...0Z, followed by 10-1Z, 20-2Z, etc.

Abdel Hamid, Sara, OB

Abdel Kader, Mahmoud, OB

Abrahamse, Heidi, 04

Agrba, Pavel, Ol

Alfieri, Domenico, OF

Altan, Hakan, ON

Arce-Diego, J. L., OK

Askoura, Mohamed-Lamine, 13, 18

Bacci, Stefano, OF

Balbekin, N. S., OM

Baubeau, E., OW

Beck, Rainer J., 1B

Belikov, Andrey V., OJ

Bergmeier, Jan, OP

Bernard, A., OW

Blondel, Walter, 05

Bogdanov, Alexey A., 1D

Brinkmann, Ralf, 00

Bucharskaya, A. B., 16

Burnett, Arthur, 17

Carter, Richard M., OT, 1B

Chang, Chun-Hung, OG

Cicchi, Riccardo, OF

Comsa, Florin, OD

Conkey, Donald B., $\mathrm{OZ}$

Cook, Stéphane, $\mathrm{OZ}$

Cordes, Jens, 00

Demhasaj, Sahit, OD

Descloux, Laurent, $0 Z$

De Siena, Gaetano, OF

Dhillon, B., OT

Dikic, Slobodan, OD

Domke, Matthias, $0 Q$

Dubina, Michael V., 1D

Dudenkova, Varvara, 01

Egaud, G., OW

Esipova, Anna, OD

Fanjul-Vélez, F., OK

Fiedler, Sebastian, 08

Fried, Nathaniel M., 0C, 0G, 17

Frobert, Aurelien, $\mathrm{OZ}$

Fuchs, Alexander, OP

Gain, P., OW

Gelfond, Mark L., OJ

Geyko, I. A., OE

Giraud, Marie-Noelle, $\mathrm{OZ}$

Gladkova, Natalia, $0 \mathrm{I}$

Goetz, Marcus, 08

Góra, Wojciech S., OT, 1B
Gorin, D. A., 16

Goy, Jean-Jacques, $0 z$

Gubarkova, Ekaterina, 01

Gunadi, Sonny, 1B

Haenggi, M., 07

Haj-Hosseini, Neda, 08

Hand, Duncan P., OT, 1B

Hardy, Luke A., OC

$\mathrm{He}, \mathrm{Z} ., \mathrm{OW}$

Hernández-González, A., OK

Hessling, M., 1 A

Homann, Christian, $0 Q$

Houreld, Nicolette Nadene, 04

Houzet, J., OW

Huber, Heinz P., OQ

Huettenberger, Dirk, OB

Irby, Pierce B., OC

Jayne, David, 1B

Jumelle, C., OW

Kahrs, Lüder A., OP

Kamburoglu, Kıvanç, ON

Karagoz, Burcu, ON

Khodzitsky, M. K., OE, OM

Kholodtsova, Maria N., 05

Kirillin, Mikhail, Ol

Kiseleva, Elena, 0

Klimenko, Vladimir $V ., 1 D$

Knyazev, Nickolay A., ID

Koch, F., 1A

Koelbl, P. S., 1A

Kuznetsova, Julia, OQ

Lagoda, Gwen A., 17

Laible, Maike, $\mathrm{OQ}$

Lange, Birgit, 00

Lanvin, Thomas, $\mathrm{OZ}$

Lazareva, Anastasia A., OJ

Le Pommellec, Jean-Yves, 13

L'Huillier, Jean-Pierre, 13, 18

Liakhov, E. P., OM

Lingenfelder, C., 1A

Loschenov, Victor B., 05

Lovisa, B., 07

Madieta, Emmanuel, 18

Markwardt, Niklas, 08

Maslyakova, G. N., 16

Matveeva, O. V., 16

Mauclair, C., OW

Mehinagic, Emira, 18

Mfouo-Tynga, Ivan, 04 
Navolokin, N. A., 16

Odlyanitskiy, E. L., OE

Oertel, M., 07

Ortmaier, Tobias, OP

Panteleeva, Olga, 0 I

Parakhuda, S. E., OE

Pasukhin, Mikhail, Ol

Pavone, Francesco S., OF

Pelayo-Fernández, M. L., OK

Pengel, Steffen, OP

Perkins, William C., 17

Perrache, C., OW

Pfleiderer, M., 07

Pini, Roberto, OF

Piron, Vianney, 13, 18

Piselli, S., OW

Pitzschke, A., 07

Plankina, Elena, 0 I

Polzer, Christoph, 08

Pongratz, Thomas, OD

Psaltis, Demetri, $\mathrm{OZ}$

Rapp, Stephan, $0 Q$

Rossi, Francesca, OF

Rühm, Adrian, 08

Salas-García, I., OK

Samsonova, Iulia S., 05

Schmedt, Claus-Georg, OD

Sedykh, E. A., OE

Serebryakova, M. K., OM

Sergeeva, Ekaterina, 0 l

Seydoux, O., 07

Shakhova, Natalia, ol

Shatilova, Ksenia V., OJ

Shephard, Jonathan D., OT, 1B

Smolyanskaya, O. A., OE, OM

Sosenkova, Svetlana A., OJ

Sroka, Ronald, OD, OQ

Stepp, Herbert, 08, OB

Strepitov, E. A., OM

Sukhorukov, G. B., 16

Sulatsky, M. I., OE

Svenskaya, Yu. I., 16

Tardy, Y., 07

Tatini, Francesca, OF

Thuret, G., OW

Trulyov, A. S., OM

Tuchin, V. V., 16

Valentin, Jeremy, $\mathrm{OZ}$

Vaudelle, Fabrice, 18

Vitkin, Alex, 0 l

von Berg, Anna, 08

Wagnières, G., 07

Wang, Peiru, 06

Wang, Xiuli, 06

Wick, Sebastian, $0 Q$

Wilson, Christopher R., OC, OG

Wittig, Rainer, OB

Yanina, I. YU., 16

Zabolotniy, A. G., OE
Zelenkov, Petr, 08

Zellweger, M., 07

Zhang, Guolong, 06

Zimmermann, Wolfgang, $O B$

viii

Proc. of SPIE-OSA Vol. 9542 954201-8 


\title{
Conference Committee
}

\author{
General Chairs
}

Andreas Hielscher, Columbia University (United States)

Jürgen Popp, Friedrich-Schiller Universität Jena (Germany)

Programme Chairs

Rainer Leitgeb, Medizinische Universität Wien (Austria)

Nirmala Ramanujam, Duke University (United States)

Conference Chairs

Lothar D. Lilge, Princess Margaret Hospital (Canada)

Ronald Sroka, Laser-Forschungslabor (Germany)

Conference Programme Committee

Stefan Andersson-Engels, Lund University (Sweden)

Wolfgang Bäumler, University Hospital Regensburg (Germany)

Nacim Betrouni, INSERM (France)

Natalia N. Bulgakova, A. M. Prokhorov General Physics Institute

(Russian Federation)

Ralf Brinkmann, Universität zu Lübeck (Germany)

Santiago Camacho Lopez, Centro de Investigación Científica y de

Educación Superior de Ensenada B.C. (Mexico)

Martin Frenz, University Bern (Switzerland)

Nathaniel M. Fried, The University of North Carolina at Charlotte

(United States)

Raimund Hibst, Universität Ulm (Germany)

Mikhail Y. Kirillin, Institute of Applied Physics (Russian Federation)

Serge R. Mordon, INSERM (France)

Carsten M. Philipp, Elisabeth Klinik (Germany)

Daniel Razansky, Helmholtz Zentrum München GmbH (Germany)

David D. Sampson, The University of Western Australia (Australia)

Herbert Stepp, University Hospital Munich (Germany)

Alfred Vogel, Universität zu Lübeck (Germany)

Georges Wagnières, Ecole Polytechnique Fédérale de Lausanne (Switzerland)

Xiu-li Wang, Shanghai Skin Diseases and STD Hospital (China)

Gang Zheng, University of Toronto (Canada) 


\section{Session Chairs}

1 Photosenitizer and Nanoparticle mediated PDT

Georges A. Wagnières, Ecole Polytechnique Fédérale de Lausanne (Switzerland)

2 Lasers and Light in the Brain

Ronald Sooka, Ludwig-Maximilians Universität München (Germany)

Herbert Stepp, Klinikum der Universität München (Germany)

3 Application of Laser in Soft Tissue

Ralf Brinkmann, Medizinisches Laserzentrum Lübeck GmbH (Germany)

4 Laser treatment Monitoring and Feedback Control

Mikhail Y. Kirillin, Institute of Applied Physics (Russian Federation)

Daniel Razansky, Helmholtz Zentrum München GmbH (Germany)

5 Application of Lasers in Hard Tissues

Raimund Hibst, Universität Ulm (Germany)

Nathaniel M. Fried, The University of North Carolina at Charlotte (United States)

6 Lasers in Opthalmology

Alfred Vogel, Universität zu Lübeck (Germany)

Martin Frenz, University Bern (Switzerland)

ECBO Post-Deadline Session

Rainer Andreas Leitgeb, Medizinische Universität Wien (Austria) 


\section{Introduction}

This year's Medical Laser Applications and Laser Tissue Interaction conference was held as part of the European Conferences on Biomedical Optics in Munich and was supported by the German Society for Laser Medicine (DGLM). Starting with the Poster Session, 14 posters were presented and discussed with the participants. There were six different sessions including six invited, and 27 regular, oral presentations covering the broad spectrum of laser applications in medicine such as ophthalmology, laser applications in soft and hard tissue, diagnosis in terms of monitoring and feedback techniques, photosensitizers and nanoparticles useful for photodynamic therapy, and laser and light in the brain.

Overall, highly motivated presenters in combination with an attentive and highly interested audience and encouraging chairs resulted in exciting discussions immediately after each lecture as well as outside the lecture hall. The attendance of the sessions was high.

Although not all presenters contributed a manuscript for publication, within this volume 29 lectures are summarized. We hope that during this conference you found new ideas for your scientific research and made new scientific contacts to improve the laser medical approaches for the benefit of patients.

We would like to thank all speakers and chairs for your motivation and cooperation, as well as all attendees for interesting and fruitful discussions and comments during these days in Munich. We hope to see you again in 2017.

Ronald Sroka Lothar Lilge 
Proc. of SPIE-OSA Vol. 9542 954201-12

Downloaded From: https://www.spiedigitallibrary.org/conference-proceedings-of-spie on 25 Apr 2023 Terms of Use: https://www.spiedigitallibrary.org/terms-of-use 